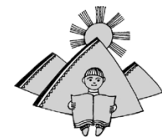

doi: $10.15330 / m s u c .2019 .20 .67-72$

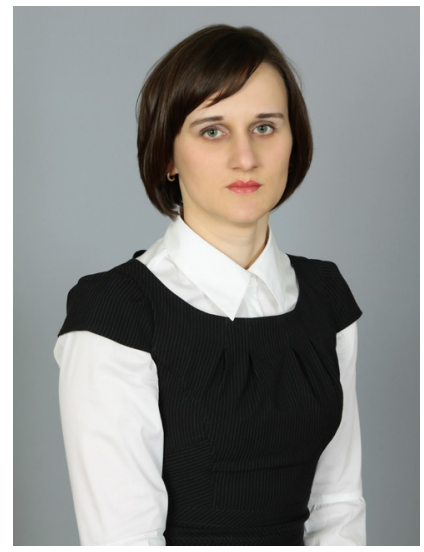

\author{
Анна Федорович, \\ кандидат педагогічних наук, доцент кафедри \\ загальної педагогіки та дошкільної освіти, \\ Дрогобицький державний педагогічний університет \\ імені Івана Франка \\ (м. Дрогобич, Україна)
}

\author{
Anna Fedorovych, \\ $\mathrm{PhD}$ in Education, Associate Professor, \\ Department of General Pedagogy and Pre-school \\ Education, Drohobych State Pedagogical University \\ named after Ivan Franko \\ (Drohobych, Ukraine) \\ f_anna_v@ukr.net \\ ORCID ID 0000-0001-6289-5039
}

УдК 373.2.011.3-051 (477.83/.86) «19»

\title{
ЗМІСТ ПІДГОТОВКИ ФАХІВЦІВ ДОШКІЛЬНОЇ ОСВІТИ В ГАЛИЧИНІ НА ПОЧАТКУ ХХ СТ.
} мету нашої статті. Иого удосконалення має здійснюватися з урахуванням педагогічного досвіду, накопиченого в час зародження системи освіти дошкільних фахівців. Методи дослідження: аналіз і синтез, систематизація та узагальнення теоретичних даних, представлених у науковій літературі.

У статті на основі аналізу системи дошкільної освіти та особливостей підготовки вихователів в Галичині на початку XX ст. розглянуто зміст навчання студентів в учительських семінаріях, на курсах підготовки та в педагогіях; виявлено, що дошкільні інституції на той час потребували фахівців різних спеціальностей: вихователів, психологів, помічниць, медиків; акцентовано, що в досліджуваний період зароджувався комплексний підхід до змісту підготовки дошкільних педагогів, студенти проходили ґрунтовне практичне та теоретичне навчання (вивчали гігієну, психологію дитини, експериментальну психологію та педагогіку, методику Ф. Фребеля, руханку з основами медицини та ін.). На поч. XX ст. в Галичині, як і на інших територіях України сформовано практичні та теоретичні основи дошкільної педагогічної освіти. Зміст підготовки дошкільних працівників поступово доповнювався і передбачав: духовний, психологічний, педагогічний, методичний, оздоровчо-гігієнічний компоненти, сутність яких потребує подальшого дослідження.

Ключові слова: дитячі заклади, фахівці дошкільної освіти, зміст навчання, теоретична та практична підготовка педагогів.

\section{CONTENTS OF PREPARATORY PREPARATION PREPARATION IN GALICHYNY AT THE BEGINNING OF XX CENTURIES}

Abstract. The content of the training of preschool children was paid insufficient attention, which determined the purpose of our article. Its improvement should be based on the pedagogical experience gained during the birth of the education system of preschool specialists. Methods: analysis and synthesis, systematization and generalization of theoretical data presented in scientific literature.

On the basis of the analysis of the system of preschool education and the peculiarities of the training of educators in Halychina at the beginning of the 20th century, the content of teaching students in the teacher's seminaries, on courses of training and in pedagogiyas is considered in the article; preschool institutions are needed specialists of different specialties (educators, psychologists, assistants, doctors) are proven in the article; in the period under study we developed a comprehensive approach to the content of the training of preschool teachers, students underwent extensive practical and theoretical training (they studied hygiene, psychology of the child, experimental psychology and pedagogy, technique by F. Frebel's, methods, movement with the basics of medicine, etc.) are accented. At the beginning of the 20th century in Halychina the practical and theoretical foundations of preschool pedagogical education have been formed. The content of the training of preschool workers was gradually supplemented and provided: spiritual, psychological, pedagogical, methodological, health and hygienic components, the essence of which requires further research.

Keywords: children's institutions, specialists in preschool education, content of training, theoretical and practical training of teachers.

\section{ВСТУП}

Постановка проблеми. Сутність освітньої політики кожної держави визначається вимогами суспільства, потребами громадськості, батьків та дітей. Через надшвидкі зміни сучасного культурного життя українського народу 
постійного оновлення потребує зміст підготовки педагогічних фахівців. Адже вони мають забезпечувати якісне виконання завдань освітнього процесу у різних виховних інституціях з конкретними віковими категоріями населення.

Особливого значення набуває робота з дітьми дошкільного віку, оскільки загальновідомо, що все подальше життя людини залежить від того, яким було її дитинство. Дитинство сьогодні вважається самоцінним етапом у житті кожного. Орієнтація педагогічної науки на особистість дитини потребує глибинного вивчення її потенційних здібностей та суб'єктних проявів, зумовлює пошук педагогічних засобів, які б забезпечували становлення та гармонійний розвиток особистості. Науковці обґрунтовують сутність дитини (біологічного, психологічного, духовного, соціального компонентів), акцентуючи увагу на їі цілісності та необхідності узгодженості, послідовності та адекватності виховних впливів [13]. Без оволодіння знань про дитину, розуміння її індивідуальності та законів розвитку в дошкільному віці неможливе розв'язання багатовекторних проблем освіти. Від того, які навчальні дисципліни засвоюватимуть майбутні вихователі в педагогічних закладах, якого досвіду набудуть, залежатиме успішність періоду дитинства, якість та результативність освітнього процесу загалом. При цьому знання традицій, психологічних особливостей рідного народу щодо виховання дітей, особливостей становлення змісту дошкільної освіти у попередні історичні періоди мають важливе значення для формування особистості сучасного фахівця. Перегляду потребує історія становлення освіти дошкільних працівників на різних територіях України.

Аналіз останніх досліджень і публікацій. Проблеми змісту професійної підготовки педагогів розглядають М. Барна, А. Булда, А. Глузман, Н. Дем'яненко, Т. Завгородня, О. Кобрій, І. Кравченко, С. Нікітчина, М. Пантюк, Л. Хомич та ін. Особливе значення для дослідження особливостей підготовки фахівців дошкільної освіти мають праці Л. Артемової, Ю. Косенко, Н. Лисенко, З. Нагачевської, Т. Слободянюк, І. Улюкаєвої та ін. Зокрема, у монографії 3. Нагачевської розкрито чинники, умови й особливості реалізації ідеї закладів дошкільного виховання у Східній Галичині та охарактеризовано форми й методи підготовки педагогічних кадрів для українських дошкільних установ.

МЕТА I ЗАВДАННЯ ДОСЛІДЖЕННЯ. Змісту підготовки вихователів дітей дошкільного віку приділено недостатньо уваги, що й визначило мету нашої статті. Його вдосконалення має здійснюватися з урахуванням педагогічного досвіду, накопиченого в час зародження системи освіти дошкільних фахівців.

МЕТОДИ ДОслІДЖЕНнЯ: аналіз і синтез, систематизація та узагальнення теоретичних даних, представлених у науковій літературі.

\section{РЕЗУЛЬТАТИ ДОСЛІДЖЕННЯ}

Початок XX ст. був суперечливим щодо розвитку української національної освіти Галичини. За короткий період змінювалося керівництво та підпорядкування краю, населення потрапляло під вплив різних політичних, громадських, освітніх організацій.

Поштовхом для самовираження українців на галицькій території стали події середини XIX ст., зокрема австрійські конституції 1848 р. та 1867 р. Вони мали позитивний вплив на піднесення активності та організаційного зростання нашого суспільства. На землях, де переважало українське населення, впроваджувалася рідна мова навчання та проголошувався його світський характер. Освітня політика Австро-Угорської монархії передбачала обов'язкову початкову освіту, відкриття закладів для підготовки вчителів народних шкіл, створення на цій базі інституцій для виховання і навчання дітей дошкільного віку. Зміни адміністративного устрою посприяли автономізації освіти. Українські школи могли підпорядковуватися греко-католицькій (українській) митрополичій консисторії.

Попри правові можливості розвитку української освіти, економічна неспроможність народу, фактична влада польської аристократії, практично суцільна неписьменність українського населення зумовлювали перешкоди та неможливість широкого її впровадження. Основним вихователем української дитини-дошкільника все ще залишалася мати. Потреби та ідеї організованого дошкільного виховання не сприймалися народом, більшість якого становили селяни. Перші заклади створювалися для дітей польських заможних родин задля підготовки до навчання в школі (їх називали «фребелівські огородці», «фребелівські шкілки», «охоронки»). Для дітей найманих робітників організовувалися охоронки з метою догляду, призвичаєння їх до чистоти й порядку, виховання добрих звичок, любові до праці. Ясла відкривалися для покинутих або найбідніших дітей віком до трьох років, щоб здійснювати лікувально-профілактичний догляд [11, с. 23 - 24]. Загалом на кін. XIX ст. у Східній Галичині функціонувало 9 фребелівських дитячих садків та 52 охоронки. Значна частина закладів, зокрема сезонні охоронки, відкривалися під проводом монахинь римо-католицького обряду. Тобто інституції для дітей дошкільного віку були створені «задля оборони польської народности», ополячували українських дітей, слугували «винародовленню» русинів-українців [11, с. 36].

На розвиток підготовки фахівців дошкільної освіти в Галичині мало вплив розпорядження Міністерства віросповідань і освіти від 22 червня 1872 р. Ним було визначено чотири її варіанти: державні семінарії; спеціальні (фребелівські) однорічні курси при жіночих семінаріях; спеціальні однорічні курси при публічних (державних) або приватних дитячих садках; приватне навчання з практикою в зразковому дитячому садку (впродовж мінімум трьох місяців). Одночасно встановлювалися вимоги до працівників різних типів дошкільних інституцій (дитячих садків, дитячих охоронок, ясел). Однак не було прописано чітких вимог до загальної мети та змісту підготовки 
вихователів [6]. Основна увага при здобутті освіти надавалася практичній підготовці - обов'язковій роботі в дитячому закладі, теоретичні дисципліни практично співпадали з тими, що вивчалися в учительських семінаріях.

За матеріальну базу дошкільного закладу відповідав засновник (державна чи громадська організація, окрема особа), педагогічний контроль і керівництво здійснювала управителька (керівничка) - особа віком понад 24 роки із закінченою вчительською семінарією і не менше ніж трьома місяцями практичної роботи. Виховання та освіта дітей провадилися вихователями («огородничками», «садівницями»), які повинні були мати освіту жіночої учительської семінарії або спеціальних однорічних курсів при них. Нянькою могла бути будь-яка особа, здорова фізично і душевно, з належними моральними якостями [11].

Як бачимо, на початку XX ст. існували всі передумови для створення та поширення закладів для підготовки вихователів дітей дошкільного віку. Однак жодної державної учительської семінарії на Галичині з українською мовою навчання не було. Доступ українців до навчальних закладів був обмеженим. До прикладу, у 1910/1911 н.р. число державних учительських семінарій становило 18 (14 чоловічих і 4 жіночі). За мовою викладання на території Західної Галичини вони були польськими, а на території Східної Галичини - утраквістичними (польсько-українськими) [5].

Небажання тогочасних державних органів влади займатися організацією освіти для русинів стало причиною того, що розв'язання проблеми здійснювалося національно свідомою частиною української громадськості. Відповідно питаннями дошкільного виховання займалася інтелігенція, гуртуючись у релігійних товариствах (Марійські дружини, товариство «Мироносиць», Сестри Василіянки, Сестри служебниці Пречистої Діви Марії) та громадських організаціях (УПТ «Рідна школа», «Просвіта», «Українська захоронка», «Жіноча громада», «Жіночий союз», «Товариство руських жінок» у Стрию, «Клуб русинок», «Союз українок» та ін.).

Наприклад, Конгрес українського жіноцтва висунув вимогу до «Рідної школи», при якій існувала «Комісія для дошкільного виховання», про заснування семінарій для підготовки фахівців-дошкільників (садівничок). Товариство відтак надало фінансову підтримку для розвитку цієї справи, зокрема для створення постійно діючих педагогічних курсів. Виховательки тут ґрунтовно вивчали психологію дошкільного виховання, методику релігійного та фізичного виховання, гігієну й ручну працю [8, с. 12].

Найперше майбутніх фахівців ознайомлювали з методикою Ф. Фребеля (мала найширше використання), а також М. Монтессорі. Згодом завдання підготовки конкретизувалися і передбачали засвоєння знань, необхідних для роботи в дитячому садку, розуміння дитячої природи, вивчення різних напрямів та засобів дошкільного виховання [6].

На початку XX ст. одним із провідних освітніх закладів Галичини, де готували педагогів для українських народних шкіл, стала вчительська семінарія, заснована 1903 р. у Львові Руським товариством педагогічним. Вона існувала завдяки пожертвам громадськості, допомозі культурно-освітніх товариств і щорічній субвенції крайового сейму. Випускники семінарії запрошувалися до роботи в дитячих закладах, оскільки вивчали психологію дитини. Таку ж приватну навчальну установу для дівчат-українок перед Першою світовою війною заснувала філія РТП в м. Коломиї (сьогодні Івано-Франківської обл.). у 1906 р. відкрито вчительську семінарію при Яворівському жіночому монастирі, а в 1909 р. - у Станіславові Сестрами Василіянками. Відзначимо, що при семінаріях діяли народні школи, захоронки, в яких майбутні педагоги «практикувалися» в методиці навчання й виховання дітей, вивчали співи, займалися працею [9].

Ще до початку Першої світової війни підготовкою виховательок для дитячих садків («провідниць») займалося товариство «Руська охоронка», сприяючи згодом навчанню фахівців на дворічних курсах при Фребелівському інституті (на українському відділенні). Також організовувались курси для перепідготовки безробітних учительок на провідниць. «Союз українок», зокрема, влаштовував пополудневі або вечірні курси на період 30 - 40 днів.

Звичайно, товариства присвячували свою діяльність, окрім дошкільної, й іншим справам, зосереджуючись на піднесенні культурного та освітнього рівня селянства, поширюючи мережі бібліотек, читалень, підтримуючи хори, театри, гімнастичні згромадження та кооперативи. Про відданість питанню народного добробуту свідчать вимоги до виховательки: «...добре знати й любити село, розуміти його психологію, відчувати його болі. Вона повинна мати ще добрий характер, національну свідомість і трудолюбивість, бути рішучою і енергійною, а при цьому лагідною до дітей» [1, с. 235].

Значущою в розвитку дошкільної освіти та підготовки виховательок була роль Української греко-католицької церкви. Саме завдяки зусиллям церкви на Галичині було створено першу захоронку для дітей-українців у 1893 р. Ї̈̈ засновником став священик Перемишльської єпархії УГКЦ, релігійний письменник і громадський діяч Кирило Селецький, який у своїй парафії в селі Жужелі (нині Жужеляни) Сокальського повіту Львівського воєводства заснував дім Сестер Служебниць, які стали опікуватися дітьми. Перебування дітей селян у захоронці уможливлювало найману працю їхніх матерів. Тут дбали про здоров'я та виховання малюків. Опікункою дітей була с. Йосафата Гордашевська, яка закінчила Львівську медичну школу і зналася на народній медицині (лікуванні травами). Ї̈̈ рідна сестра Арсенія Гордашевська стала першою вихователькою. Попередньо с. Арсенія отримала педагогічну освіту у Львові та пройшла практичні курси з ведення захоронок у римо-католицьких Сестер Феліціанок у Жовкві (Боршовська).

Захоронки Сестер Служебниць набули поширення та виконували благодійну опіку над дітьми дошкільного віку від 3 до 7 років, дбаючи про їх духовний, розумовий, культурний, патріотичний та фізичний розвиток. У кожному монастирі, де діяла захоронка, черниці мали бібліотеки з дидактичними матеріалами та посібниками 
педагогічного спрямування, ілюстровані матеріали, шкільні приладдя та іграшки. Релігійне виховання займало найбільше місце. Кожен день починався ранковою молитвою, а закінчувався вечірньою; молилися діти перед і після обіду. Урочисто відзначалися великі греко-католицькі свята [1]. До кола обов'язків виховательок входило: ведення книги реєстрації дітей (із зазначенням прізвища, імені, дати та місця народження дитини, а також роду занять її батьків) та спеціального журналу для запису спостережень за кожним вихованцем; підбір методичнодовідкової літератури для працівників та відповідних книжечок до дитячої бібліотеки [7].

Уся система українського дошкільного виховання того часу базувався на народних виховних традиціях, принципах етнопедагогіки, моральних засадах християнства. Ї̈̈ зміст передбачав дидактичні, рухливі ігри, вивчення елементів ручної праці, формування початкових математичних уявлень, підготовку руки до письма, малювання, навчання співу, декламування та вивчення віршів, читання оповідань. Ігри, вірші, пісні для дітей ґрунтувалися на народному фольклорі [12]. Увібравши 3 методики Ф. Фребеля найцінніше, в українських захоронках значна увага приділялася національному змісту виховання та збереженню рідної мови.

Підкреслимо, що в дитячих закладах здійснювалися періодичні безкоштовні медогляди дітей. Діти часто хворіли простудними хворобами через відсутність печей та погане опалювання приміщень. Згідно з укладеними з Українським лікарським товариством домовленостями, лікарі стежили за здоров'ям дітей, одночасно пропагували основи санітарно-гігієнічних знань працівникам, можливості профілактики захворювань, здійснювали широку просвітницько-роз'яснювальну роботу, пропаганду й виховання здорового способу життя серед населення через пресу, лекції [2]. Це, звичайно, мало цінний вплив на підготовку виховательок та розширення їхніх знань про дитину, її фізичне здоров'я, потреби гігієни, особливості харчування, догляду, лікування. Позитивним щодо медичної просвіти було відкриття «Порадні для матерів» у Львові (за сприяння митрополита Андрея Шептицького), де жінки могли отримати моральну та грошову підтримку, фахову юридичну консультацію, тут обстежували немовлят та надавали допомогу кваліфіковані педіатри.

Отож, перші заклади дошкільного виховання потребували (і мали) помічниць, медичних сестер, садівниць, а згодом стало зрозуміло, що й психологів, оскільки педагогічна робота потребувала комплексного вивчення кожної дитини (спостереження, ведення щоденників, індивідуальний підхід, догляд і т. ін.). Значна частина працівників цих інституцій мали широку підготовку з різних галузей знань, поєднуючи медичну й педагогічну освіти.

Та не всі розуміли значення української захоронки для розвитку дитини. Часто батьки обирали польську, розташовану ближче до дому чи з метою опанування дитиною польської, а не української мови. До того ж місцева влада відмовляла в оренді приміщень під дошкільні заклади, звільняла виховательок, які не знали польської мови, чинила всякий спротив та дискримінацію на всіх рівнях, загострюючи ворожнечу між поляками та українцями.

у 1911/1912 н.р. загальна кількість захоронок у Галичині зросла до 194, а дитячих садків - до 32 . На фоні цієї статистики українські дошкільні заклади виглядали невеликими острівцями опіки, виховання та підготовки дітей до навчання в українських школах. За даними Українського педагогічного товариства, у 1913/1914 н. р. вони налічували 10 дитячих садків і 13 захоронок, утримуваних громадськими організаціями та греко-католицькими чернечними об'єднаннями [11, с. 60 - 61].

Незважаючи на те, що педагогічні заклади створювалися приватно для українських дітей, польська шляхта постійно провадила політику утраквізму. Подальші події, світова війна, більшовицький переворот, функціонування Центральної Ради ще більше ускладнили польсько-українські відносини.

У 20-х рр. XX ст. двомовне навчання в Галичині стало обов'язковим, і українські освітні інституції фактично опинилися поза законом. Освітні реформи Польської республіки в наступні роки мали нищівний характер та згубно вплинули на розвиток педагогічних закладів Галичини.

Цьому намагалася протистояти прогресивна галицька громадськість. Попри всі негативні умови існування української освіти, саме в цей період зароджується національна система дошкільного виховання. Завдяки наполегливій праці діячів усієї території України (І. Блажкевич, Ю. Дзерович, А. Животко, С. Русова, С. Сірополко, Л. Ясінчук та ін.), ідеї яких перепліталися, вдалося обґрунтувати концепцію дошкільної освіти та визначити вимоги до особистості вихователя дітей дошкільного віку.

Зміна устрою та структури системи освіти у 30-х рр. XX ст. позначилися на навчанні педагогів, що тепер мало відбуватися в чотирирічних семінаріях та дворічних ліцеях для вихователів дошкільних закладів. Семінарії приймали на перший рік навчання кандидатів, яким виповнилося не менше 13 років, на основі змісту другого програмного рівня початкової школи, передбачаючи загальне навчання, суспільно-громадську і педагогічну підготовку та педагогічну практику. Ліцеї приймали кандидатів, яким виповнилося 16 років, а програма ґрунтувалася на програмі загальної гімназії. Були ліквідовані п'ятирічні вчительські семінарії [4, с. 42]. Окрім ліцеїв, оволодіти професією вчителя можна було у дворічних «педагогіях», які базувалися на гімназіях «старого» (класичного) типу. Для підготовки вихователів дошкільних закладів мали відкриватися спеціальні «захоронкові» семінарії [5].

У 1937 р. у Львові було створено нову педагогічну школу - Державну «Педагогію» із дворічним терміном навчання. Серед трьох галицьких воєводств вона була єдиним закладом вищого рівня. На жаль, усі виклади в ній проводилися польською мовою, за винятком предмету української мови. До цього часу педагогії вже функціонували у Варшаві, Кракові, Любліні, Познані, Лодзі та ін. містах. У їх відділеннях постійно резервувалися місця лише для польських студентів, українці вступали сюди вкрай рідко [10]. 
У «Педагогії» вивчалися найбільше педагогічні предмети (історія навчання, головні течії і методи у всесвітньому навчанні й вихованні, психологія, дидактика й методика навчання) та здійснювалася піврічна практика в різних народних школах Львова. Основою педагогічної підготовки були предмети: загальна філософія, соціологія, економія, біологія. Найбільшу увагу приділяли психології передшкільного віку (психологія дитини, читав д-р П. Домбровський), психології шкільного віку та психології модерного напряму (експериментальній психології) 3 піврічним записом спостережень за конкретним вихованцем. Вивчення психології базувалося на християнському світогляді. Також зміст навчання передбачав засвоєння таких обов'язкових дисциплін: спів, рисунки, ручні роботи і руханка. При цьому лекції з руханки не були практичними вправляннями, а теоретичними, пов'язаними зі студіями медицини [10].

Таким чином, на поч. XX ст. в Галичині, як і на інших територіях України, було сформовано практичні й теоретичні основи дошкільної педагогічної освіти. Підготовка фахівців пов'язувалася насамперед з поширенням та розвитком закладів для виховання дітей. Саме в них педагоги мали змогу набувати досвіду практичної діяльності як важливої компоненти професійної освіти. На базі дошкільних закладів часто відбувалося й теоретичне навчання, виклади з гігієни, психології дитини, експериментальної психології, педагогіки, методики та ін. Напрацьовані матеріали було узагальнено в одному з перших підручників для провідниць, що виданий товариством «Рідна школа» у Львові у 1936 р. під назвою «Українське дошкілля». Він базувався на ідеях національного садка Софії Русової та мав такі розділи: «Дитячий садок», «Виховання дитини», «Гігієна в дитячому садку», «Методи занять у дитячому садку», «Пісня та забави», «Дитяча розвага» [1, с. 243].

\section{ВИСНОВКИ ТА ПЕРСПЕКТИВИ ПОДАЛЬШИХ ДОСЛІДЖЕНЬ}

Попри труднощі, недержавний статус української освіти, у досліджуваний нами період розширювалася мережа закладів дошкільної освіти, утвердилася система підготовки фахівців для закладів дошкільного виховання, було розроблено методичні та організаційні основи роботи з дітьми. Послуговуючись офіційною концепцією виховання, вихідними у змісті діяльності виховательок для дітей-українців були засади національного виховання (через вивчення рідної мови, усної народної творчості, використання народних виховних традицій, принципів етнопедагогіки). Водночас система дошкільної освіти ґрунтувалася на європейських традиціях виховання дітей, представлених здебільшого спадщиною Ф. Фребеля.

Дошкільні інституції на той час потребували фахівців різних спеціальностей: вихователів, психологів, помічниць, медиків. Тому зміст підготовки дошкільних працівників поступово доповнювався й ускладнювався, передбачаючи: духовний, психологічний, педагогічний, методичний, оздоровчо-гігієнічний компоненти, сутність яких потребує подальшого дослідження.

\section{СПИСОК ВИКОРИСТАНИХ ДЖЕРЕЛ}

Артемова, Л. (2006). Історія педагогіки України. Київ: Либідь.

Білавич, І. Становлення і розвиток громадської системи охорони здоров'я в Галичині наприкінці XIX - на початку XX CT. URL: https://www.sworld.com.ua/simpoz4/65.pdf

Боршовська, О. 120 років Сестри Служебниці Непорочної Діви Марії займаються дошкільною освітою. URL: http://credo. pro/2013/05/83033.

Завгородня, Т. (1999). Підготовка вчителів для української народної школи Галичини (1919 - 1933 р.). Івано-Франківськ: Плай.

Івах, С. (2018). Передумови освітньої діяльності представниць жіночого руху у контексті розвитку українського шкільництва Галичини (кінець XIX - перша третина XX ст.). Людинознавчі студії: зб. наук. праць дДпу імені Івана Франка. Серія «Педагогіка». 7/39, 85-103.

Квасецька, Я. (2014). Нормативно-правова база і організаційні засади функціонування фахових навчальних закладів з підготовки вихователів у західній Україні (остання третина XIX - початок XX ст.). Збірник наукових праць «Педагогіка та психологія». Харків. 46, $194-203$.

Комар, І. (2012). Навчально-виховні заклади УГКЦ як осередки духовно-морального виховання молодого покоління. Наукові записки. Серія «Психологія і педагогіка». 21, 32 - 40. URL: https://eprints.oa.edu.ua/2460/1/7.pdf

Лисенко, Н., Кирста, Н. (2006). Педагогіка українського дошкілля. Київ: Вища школа.

Маслій, Г. (2013). Специфіка функціонування жіночих навчальних закладів професійного спрямування в Західній Україні (кінець XIX- початок XX століть). Обрії. 2, 59 - 61.

Мащак, В. (1985). Маловідома педагогічна школа у Львові (Спомин). Визвольний шлях: суспільно-політичний і науково-літературний місячник. 6 (447), $747-758$.

Нагачевська, 3. (2015). Українське дошкілля в освітньому просторі Східної Галичини (кінець ХІХ ст. - 1939 р.). Івано-Франківськ: HAIP.

Щербяк, Ю. (2014). Опікунська діяльність греко-католицької церкви кінця XIX ст. - 1939 рр. Педагогічний альманах. Херсон. $21,253-260$.

Wing Han Lamb W. (2001). The «Whole Child» in Education. Journal of Philosophy of Education. Vol. 35. Issue 2.

\section{REFERENCES}

Artemova, L. (2006). Istoriia pedahohiky Ukrainy. Kyiv: Lybid.

Bilavych, I. Stanovlennia i rozvytok hromadskoi systemy okhorony zdorovia v Halychyni naprykintsi XIX - na pochatku XX st. Retrieved from: https://www. sworld.com.ua/simpoz4/65.pdf 
Borshovska, O. 120 rokiv Sestry Sluzhebnytsi Neporochnoi Divy Marii zaimaiutsia doshkilnoiu osvitoiu. Retrieved from: http://credo. pro/2013/05/83033

Zavhorodnia, T. (1999). Pidhotovka vchyteliv dlia ukrainskoi narodnoi shkoly Halychyny (1919 - 1933 r.). Ivano-Frankivsk: Plai.

Ivakh, S. (2018). Peredumovy osvitnoi diialnosti predstavnyts zhinochoho rukhu u konteksti rozvytku ukrainskoho shkilnytstva Halychyny (kinets XIX - persha tretyna XX st. Liudynoznavchi studii: zb. nauk. prats DDPU imeni Ivana Franka. Seriia «Pedahohika», 7/39, 85-103.

Kvasetska, Ya. (2014). Normatyvno-pravova baza i orhanizatsiini zasady funktsionuvannia fakhovykh navchalnykh zakladiv z pidhotovky vykhovateliv u zakhidnii Ukraini (ostannia tretyna XIX - pochatok XX st.). Zbirnyk naukovykh prats «Pedahohika ta psykholohiia». Kharkiv. 46, $194-203$.

Komar, I. (2012). Navchalno-vykhovni zaklady UHKTs yak oseredky dukhovno-moralnoho vykhovannia molodoho pokolinnia. Naukovi zapysky. Seriia «Psykholohiia i pedahohika».21, 32 - 40. Retrieved from: https://eprints.oa.edu.ua/2460/1/7.pdf

Lysenko, N., Kyrsta, N. (2006). Pedahohika ukrainskoho doshkillia. Kyiv: Vyshcha shkola.

Maslii, H. (2013). Spetsyfika funktsionuvannia zhinochykh navchalnykh zakladiv profesiinoho spriamuvannia v Zakhidnii Ukraini (kinets XIX - pochatok XX stolit). Obrii. 2, $59-61$.

Mashchak, V. (1985). Malovidoma pedahohichna shkola u Lvovi (Spomyn). Vyzvolnyi shliakh: suspilno-politychnyi i naukovoliteraturnyi misiachnyk. 6 (447), 747 - 758.

Nahachevska, Z. (2015). Ukrainske doshkillia v osvitnomu prostori Skhidnoi Halychyny (kinets XIX st. - 1939 r.). Ivano-Frankivsk : NAIR.

Shcherbiak, Yu. (2014). Opikunska diialnist hreko-katolytskoi tserkvy kintsia XIX st. - 1939 rr. Pedahohichnyi almanakh. Kherson. $21,253-260$.

Wing Han Lamb W. (2001). The «Whole Child» in Education. Journal of Philosophy of Education. Vol. 35. Issue 2.

Статтю подано до редколегії 14.03.2019 р.

Рекомендовано до друку 04.04.2019 p. 